\title{
TRENDS OF CHANGE REGARDING POVERTY IN THE REPUBLIC OF SERBIA IN THE PERIOD 2006-2010
}

\section{Biljana Grujić}

Institute of Agricultural Economics, Belgrade, Serbia

\biljana_g@iep.bg.ac.rs

\section{Svetlana Roljević}

Institute of Agricultural Economics, Belgrade, Serbia

$\bowtie$ svetlana_r@iep.bg.ac.rs

\section{Nataša Kljajić}

Institute of Agricultural Economics, Belgrade, Serbia

$\triangle$ natasa_k@iep.bg.ac.rs

\section{UDC}

$364.662(497.11)$

"2006/2010"

Review paper

Received:

22.08 .2013

Accepted:

14.04.2014

\begin{abstract}
The purpose of the study was to assess poverty in Serbia in the period 2006-2010. This paper analyzes the percentage of the poor by: type of neighborhood, regional distribution, household type, age, involvement of children and adults, level of education and socio - economic status of the household. The following methods of descriptive statistics were applied: the average value of the appearance, the interval of variation, standard deviation, coefficient of variation and the rate of change. It points to the differences in the values of consumer units denominated in RSD, which is used as a threshold for determining the percentage of the poor population. The research results indicate that the poorest are multi-member households and adults at the age of 19-24.
\end{abstract}

Keywords: poverty, poverty rate, the poverty threshold, aspects of poverty, statistics indicators

Paper work is part of the project research 46006 ,Sustainable agriculture and rural development in function of Republic of Serbia strategic goals achievement within the Danube region “, and project 179028 ,, Rural work market and rural economics of Serbia diversification of income and decrease of rural poverty" financed by the Ministry of Education, Science and Technological Development of the Republic of Serbia. 


\section{Introduction}

The definition of poverty is based on the notion of participation. EU Council of Ministers in 1975, defined poor individuals as "individuals or families whose resources are so small as to exclude them from the minimum acceptable way of life in the Member State in which they live." Resources are defined as "goods, cash income and services from public and private sources." In this way poverty is defined in relative terms (SPC, 2011). Republic of Serbia signed a Stabilization and Association Agreement and applied for admission to the $\mathrm{EU}$, and the issues of social inclusion and poverty reduction in the coming period will become a mandatory component of the policy of integration into the EU. The Government of the Republic of Serbia is committed to meet the requirements set by the EU in the framework of the new EU Development Europe 2020 which was accepted in June of 2010. Kronja et al. (2011) point out that the Europe 2020 strategy aims at economic development of the EU is based on the knowledge to protect the environment, high levels of employment, productivity and social cohesion.

For purposes of measuring poverty in Serbia absolute and relative poverty line are used. Below the absolute poverty line are adults whose monthly expenditures are lower than the minimum amount required for food and other expenses, which include clothing, housing, health, education, transport, recreation and culture, and expenditure on other goods and services. Imputed rent and expenditure on durables are not included in the analysis. The relative poverty line defines poverty in relation to the national standard of living and is determined as equivalent for $60 \%$ of average consumption per adult.

According to Živkov et al. (2012) poverty, quality of life and the degree of vulnerability of the population are the main determinants of disparities and the lack of social justice when considering urban and rural areas. When talking about the uniform and equitable social policy in relation to rural areas, this issue should be considered at three levels. The first level refers to the general support for the development of rural areas. The second level involves consideration of rural specificities that make them different from urban areas. The third level involves recognition specificity between very rural territories.

\section{Materials and methods}

The research work follows the tendency of changes in the total number of the poor population in Serbia according to different criteria. In the five-year period (2006-2010) the different causes of poverty were analyzed. Percentage annual indicators of poor people to the various categories were compared with the total population by age, resulting with the absolute values of the poor. The same values were used for calculating the parameters descriptive statistics. A 
computer program to process parameters of descriptive statistics is Microsoft Excel 2010, and then the same data were presented in a table with the interpretation of the value indicators.

Analysis of Poverty using standard statistical methods, and by the age of observation, included the following aspects: the type of settlement (urban and rural area), by region (Belgrade, Vojvodina and Central Serbia), by type of household (one-, two-, three-man, four-, a five-member, six-member and more), by age (children under 13, children aged 14 to 18 , adults 19 to 24, adults age of 25 to 45 , adults 46 to 64 , aged 65 years and over), by age (children and adults), according to the education of the household head (primary education, primary school, secondary school, college and high school), according to the socio economic status of the household head (self-employed, employed, unemployed, retired, and other inactive).

The collected data were analyzed using standard statistical methods:

- The average value of the phenomenon;

- interval of variation (minimum and maximum);

- standard deviation;

- coefficient of variation and

- rate changes.

The rate of change can be calculated directly from the absolute values of the time series, using the following expression:

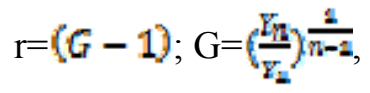

where: $r$ is the annual rate of change; $G$ is a constant relative change phenomena, $Y 1$ is the absolute value of the first article of the time series, $Y n$ representing the absolute value of the last member of the time series, $n$ is the number of series or the number of years (Novković et al., 2011) .

The research used data from the annual publication of the Statistical Office of the Republic of Serbia and appropriate literature. At the same time, we used data from the official website of the Social Inclusion and Poverty Reduction Unit, which systematically monitor the percentage of poverty indicators for different aspects.

\section{Poverty in Republic of Serbia}

According to Cvejić et al. (2010) Serbia is a low urbanized country in European terms. In addition to the low share of urban population, Serbia is characterized by a low level of infrastructure. The afore mentioned characteristics of many rural areas makes it unattractive for economic investment and housing, which is contrary to trends in highly urbanized countries. 
About $45 \%$ of the total population lives in rural areas, which cover almost three quarters of the country. According to results of the Living Standards Measurement Survey (LSMS ), conducted in May/June of 2002, about $58 \%$ of the poor population of Serbia lives in rural areas. The share of the poor among the rural population is $14.2 \%$. This is more than the percentage of the poor at the total population, which is $10.6 \%$, almost double compared to the poverty in the cities, which is $7.8 \%$. This means that one person among seven of them in rural population is poor (Popović et al ., 2008). SLS, which is realized during 2002 and 2003 , showed that $14 \%$ of the population, or approximately one million people in the Republic of Serbia live below the absolute poverty line and the poverty line was 4,970 RSD per month per household.

LSMS in 2007 shows that poverty is predominantly a rural phenomenon in Republic of Serbia. The poverty rate is twice as high in rural areas than in urban areas ( $9.8 \%$ vs. $4.3 \%)$. Differences in poverty between urban and rural areas are enhanced between the two LSMS (2002 and 2007), indicated by the increased ratio of rural to urban poverty from 1.6 to 2.3 (Cvejić et al., 2010).

In Republic of Serbia poverty is exposed to population living in non-urban areas, then the multi-member households (especially those that are composed of several children, the unemployed and inactive members), households with a lower educational level and so on (Grujić et al., 2013).

Graphs 1 and 2 give movement of Poverty showing absolute and relative poverty, as two aspects of computing the percentage of the poor population. However, the percentage of the total poor population and differences between the two types of computing might be seen.

Graph. 1. The absolute poverty line in RS (RSD)

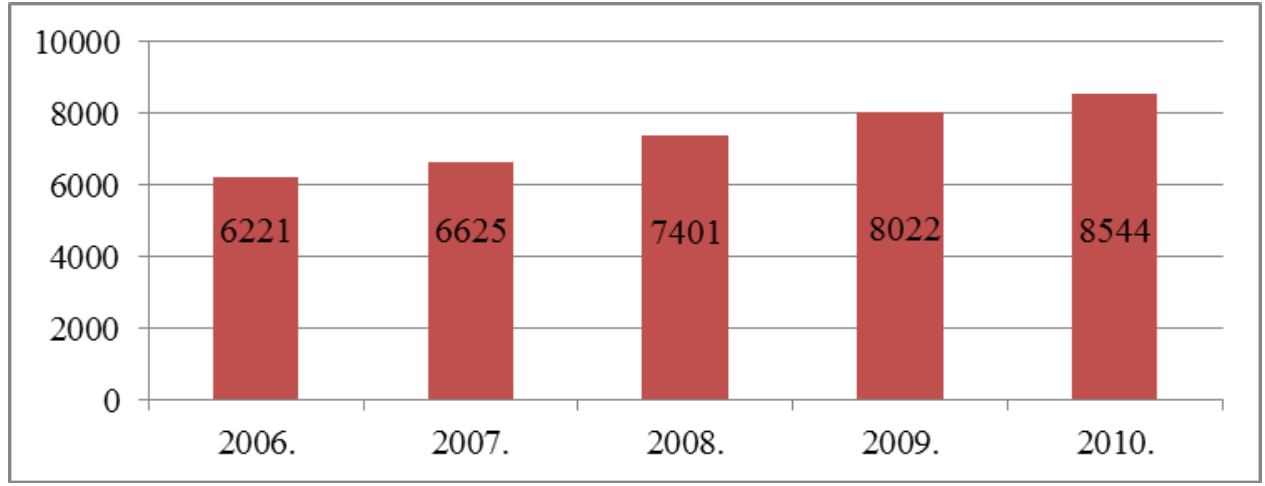

Source: http://www.inkluzija.gov.rs/?page_id=3179\&lang=cs

The absolute poverty line indicates that the percentage of poor people since 2006 to 2008 dropped by $2.7 \%$, and in 2010 comparing to 2008 (the minimum 
rate of poverty) increased by $3.1 \%$. Thus, in 2010 there were $0.4 \%$ more poor inhabitants comparing to 2006 although the absolute poverty line rose by 2,323 RSD, ie. to $37.34 \%$. Generally, in the five-year period observed the absolute poverty line has steadily increased, while the percentage of poor was varying (decreases and increases). In 2010 the population with earnings below 8,544 RSD considered to be poor (9.2\% of the population).

Graph. 2. The relative poverty line in RS (RSD)

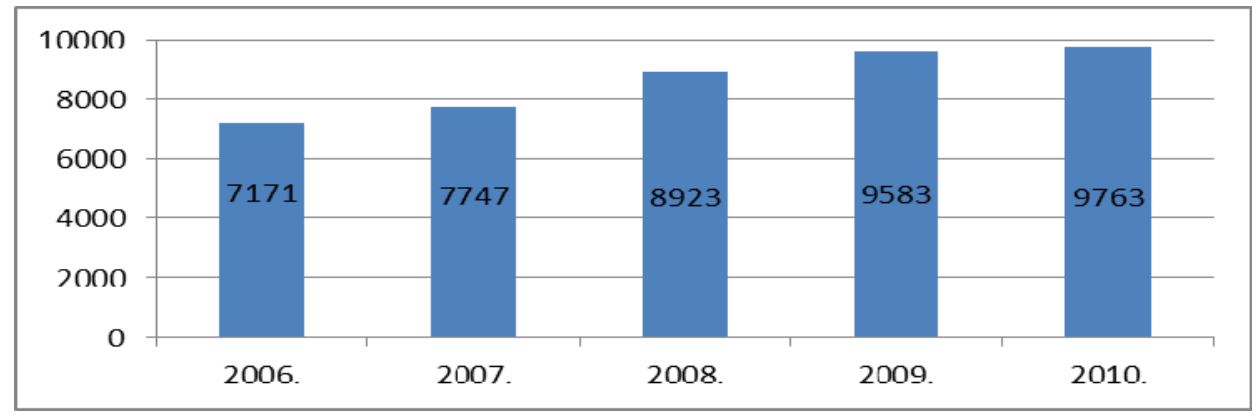

Source: http://www.inkluzija.gov.rs/?page_id=3179\&lang=cs

The relative poverty line, which is defined as $60 \%$ of private consumption per adult equivalent, according to the 2010 in the Republic of Serbia was 14.5\% poor population, a poverty line was 9,763 RSD per month per consumer unit. Percentage of poor in 2006 was $14.4 \%$ and the poverty line was 7,171 RSD per shopping cart. The lowest percentage of poor was in the 2008 (13.2\%), and the value of the poverty line was $8.923 \mathrm{RSD}$. Accordingly, although the poverty line increased, the percentage of poor varied (in the period $2006-2008$ declined, and in the period $2008-2010$ increased).

In accordance with previous findings for both forms of expression the percentage of the poor population is reasonable, and obvious explanation is that there is a simultaneous increase in unemployment and inflation, which in turn affects the growth rates of poverty RS (Grujić et al., 2013).

\section{Analysis of changes in poverty in Republic of Serbia}

Socio - economic structure of family farms is an important indicator of overall economic diversification and the situation in Serbia. The transition period was marked by significant changes in the socio - economic structure of households, caused by natural reproduction process, and the influence of social and economic reforms (Božić et al., 2006).

The percentage of poor by settlement. The percentage of poor people living below the absolute poverty recorded growth in both urban and rural areas. 
Table 1. The percentage of poor by settlement in RS

\begin{tabular}{cccccc}
\hline Area & $\begin{array}{c}\text { Average } \\
\bar{X}\end{array}$ & $\begin{array}{c}\text { Interval } \\
\text { variation } \\
\text { Min }\end{array}$ & $\begin{array}{c}\text { Standard } \\
\text { deviation }\end{array}$ & $\begin{array}{c}\text { Coefficient of } \\
\text { variation } \boldsymbol{C}_{\boldsymbol{v}(\%)}\end{array}$ & $\begin{array}{c}\text { Rate } \\
\text { changes } \\
\boldsymbol{r}(\%)\end{array}$ \\
\hline $\begin{array}{c}\text { Metropolitan } \\
\text { area }\end{array}$ & 395.510358 .720442 .895 & $30.964,97$ & 7,83 & 0,14 \\
Rural Area & 811.635551 .267991 .635 & $168.865,4$ & 20,81 & 0,01 \\
\hline
\end{tabular}

Source: $\mathrm{http}: / /$ www.inkluzija.gov.rs/?page_id=1490; author's calculation.

The average number of poor in an urban areas was 395,510 inhabitants. The number of poor ranged from 358,720 to 442,895 inhabitants, with a standard deviation of 30,964.97. The coefficient of variation in the analysis of realized value of 7.83 with a positive rate of change of $0.14 \%$. The average number of poor out of urban area was 811,635 inhabitants. The number of poor ranged from 551,267 to 991,635 inhabitants, with a standard deviation of 168,865.4. The coefficient of variation in the analysis ensures high 20.81 value with a positive rate of change of $0.01 \%$. Therefore, the greater is the presence of the average number of poor people in rural than in urban areas.

The percentage of poor people, by regions. Structure of the poor can be shown on the basis of regional distribution, with the most vulnerable region of Central Serbia.

Table 2. The percentage of poor people, by regions in RS

\begin{tabular}{cccccc}
\hline Region & $\begin{array}{c}\text { Average } \\
\overline{\boldsymbol{X}}\end{array}$ & $\begin{array}{c}\text { Interval } \\
\text { variation } \\
\text { Min } \quad \text { Max }\end{array}$ & $\begin{array}{c}\text { Standard } \\
\text { deviation }\end{array}$ & $\begin{array}{c}\text { Coefficient of variation } \\
\boldsymbol{C}_{\boldsymbol{v}(\%)}\end{array}$ & $\begin{array}{c}\text { Rate } \\
\text { changes } \\
\boldsymbol{r} \text { (\%) }\end{array}$ \\
\hline Belgrade & 274.730177 .158386 .446 & $74.481,17$ & 27,11 & 0,48 \\
Vojvodina & 574.031358 .720878 .408 & $175.866,22$ & 30,64 & $-0,63$ \\
$\begin{array}{c}\text { Central } \\
\text { Serbia }\end{array}$ & 705.541514 .516874 .972 & 122.606 & 17,38 & 0,25 \\
\hline
\end{tabular}

Source: Social Inclusion and Poverty Reduction Unit and Statistical Office of the Republic of Serbia, 2012; author's calculation.

The highest average of poor population is recorded in the Central Serbia $(705,541)$ and Vojvodina $(574,031)$ and the lowest in Belgrade $(274,730)$. Number of poor people in Central Serbia ranged from 514,516 to 874,972, in Vojvodina 358,720 to 878,408 and in Belgrade from 177,158 to 386,446 . The standard deviation in Central Serbia was 122,606, in Vojvodina 175,866.22 and Belgrade 74,481.17. The coefficient of variation was highest in Vojvodina $30.64 \%$, followed by Belgrade 27.11\% and the lowest was noticed in Central 
Serbia $17.38 \%$. In the five-year period (2006-2010) highest rate changes were recorded in Belgrade $(0.48 \%)$, followed by Central Serbia $(0.25 \%)$, while Vojvodina has achieved negative growth $(-0.63 \%)$ and indicates a gradual decline in poor population.

The percentage of poor households, by type. The most vulnerable households are those with five, six or more members since their incidence of poverty is above the national average and the highest compared with other demographic groups. A slight decrease in the number of the poor are recorded only with single-member household.

Table 3. The percentage of poor households, by type in RS

\begin{tabular}{ccccccc}
\hline Households & $\begin{array}{c}\text { Average } \\
\bar{X}\end{array}$ & \multicolumn{2}{c}{ Interval variation } & $\begin{array}{c}\text { Standard } \\
\text { deviation }\end{array}$ & $\begin{array}{c}\text { Coefficient of } \\
\text { variation } \boldsymbol{C}_{\boldsymbol{v}(\%)}\end{array}$ & $\begin{array}{c}\text { Rate } \\
\text { changes } \\
\boldsymbol{r} \text { (\%) }\end{array}$ \\
\hline One-person & 519.539 & 408.320 & 649.579 & $104.700,23$ & 20,15 & $-1,11$ \\
Two-persons & 513.667 & 404.262 & 679.105 & $121.867,54$ & 23,73 & $-1,01$ \\
Three-persons & 399.680 & 361.697 & 510.401 & $55.952,09$ & 14,00 & 0,70 \\
Four-persons & 404.183 & 344.078 & 517.692 & $63.948,75$ & 15,82 & 0,51 \\
Five-persons & 573.133 & 382.212 & 853.098 & $168.225,91$ & 29,35 & 0,82 \\
$\begin{array}{c}\text { Six and more } \\
\text { members }\end{array}$ & 1.063 .104 & 735.022 & 1.282 .201 & $186.441,94$ & 17,54 & $-0,17$ \\
\hline
\end{tabular}

Source: Social Inclusion and Poverty Reduction Unit and Statistical Office of the Republic of Serbia, 2012; author's calculation.

The highest average of poor people achieve households with six or more members $(1,063,104)$, and with the decline in household size reducing the number of poor people. The lowest number of poor people belong to the category of three-member families $(399,680)$. In the six-member family number of the poor is in the range of 735,022 to $1,282,201$ inhabitants, and the tripartite is in the range of 361,697 to 510,401 inhabitants. The standard deviation of sixmembered family is 186,441.94, and of a three-member 55,952.09. The coefficient of variation of the highest value is achieved in the five-member families $(29.35 \%)$, and lowest in the three-member households (14\%). The rate of change of the highest positive value is realized at five-members $(0.82 \%$ and the highest negative value in single-member households $(-1.11 \%)$.

The percentage of poor people by age. The increase in poverty was recorded in all ages of the population, and the smallest increase in poverty was recorded in the category of elderly people over 65 years of age. 
Table 4. The percentage of poor people by age in RS

\begin{tabular}{|c|c|c|c|c|c|c|}
\hline Age (years) & $\begin{array}{c}\text { Average } \\
\bar{X}\end{array}$ & $\begin{array}{c}\text { Interval } \\
\text { Min }\end{array}$ & $\begin{array}{c}\text { variation } \\
\text { Max }\end{array}$ & Standard deviation & $\begin{array}{l}\text { Coefficient of } \\
\text { variation } C_{v}(\%)\end{array}$ & $\begin{array}{c}\text { Rate } \\
\text { changes } \\
r(\%)\end{array}$ \\
\hline $\begin{array}{l}\text { Children } \\
\text { up to } 13\end{array}$ & 787.882 & 536.566 & 998.927 & $154.489,66$ & 19,61 & 0,38 \\
\hline $\begin{array}{l}\text { Children } \\
\text { from } 14 \text { to } 18\end{array}$ & 660.473 & 507.165 & 867.154 & $116.979,16$ & 17,71 & $-0,67$ \\
\hline $\begin{array}{l}\text { Adults } \\
\text { from } 19 \text { to } 24\end{array}$ & 568.411 & 433.663 & 838.515 & $140.921,95$ & 24,79 & 1,14 \\
\hline $\begin{array}{c}\text { Adults } \\
\text { from } 25 \text { to } 45\end{array}$ & 530.758 & 367.511 & 648.938 & $103.109,17$ & 19,43 & 0,10 \\
\hline $\begin{array}{c}\text { Adults } \\
\text { from } 46 \text { to } 64\end{array}$ & 474.845 & 388.003 & 583.315 & $74.116,13$ & 15,61 & 0,29 \\
\hline $\begin{array}{l}\text { Aged } 65 \\
\text { and over }\end{array}$ & 635.562 & 549.061 & 760.303 & $94.703,28$ & 14,90 & $-0,63$ \\
\hline
\end{tabular}

Source: Social Inclusion and Poverty Reduction Unit and Statistical Office of the Republic of Serbia, 2012; author's calculation.

The highest average number of poor children belonging to the age of 13 $(787,882)$ and ranged from 536,566 to 998,927 inhabitants. The lowest average number of poor is in the category of adults 46 to 64 years $(474,845)$ and ranged from 388,003 to 583,315 inhabitants. Standard deviation of children up to age 13 is $154,489.66$, with the coefficient of variation of $19.61 \%$ and a positive average change of $0.38 \%$. Adults from 46 to 64 years achieved a standard deviation of $74,116.13$, the coefficient of variation of $15.61 \%$ and a positive rate of change of $0.29 \%$.

The percentage of poverty by children and adults. Increasing poverty was recorded in children and adults since 2008, but the number of poor children in Serbia is growing significantly which is worrying.

Table 5. The percentage of poverty by children and adults in RS

\begin{tabular}{|c|c|c|c|c|c|c|}
\hline \multirow{2}{*}{ Age } & \multirow{2}{*}{$\begin{array}{c}\text { Average } \\
\bar{X}\end{array}$} & \multicolumn{2}{|c|}{$\begin{array}{c}\text { Interval } \\
\text { variation }\end{array}$} & \multirow[t]{2}{*}{$\begin{array}{l}\text { Standard } \\
\text { deviation }\end{array}$} & \multirow{2}{*}{$\begin{array}{l}\text { Coefficient of } \\
\text { variation } C_{v}(\%)\end{array}$} & \multirow{2}{*}{$\begin{array}{c}\text { Rate } \\
\text { changes } \\
r(\%)\end{array}$} \\
\hline & & Min & Max & & & \\
\hline Childrens & 745.413 & 521.866 & 889.555 & $133.319,96$ & 17,89 & 0,09 \\
\hline Adults & 539.626 & 426.313 & 619.772 & $77.800,07$ & 14,42 & 0,05 \\
\hline
\end{tabular}

Source: http://www.inkluzija.gov.rs/?page_id=1490; author's calculation. 
In the table it might be seen that there are more poor children than adults. The average number of poor children is 745,413 and 539,626 of adults. Number of poor children is in the range 521,866 - 889,555 and of adults $426,313-$ 619,772 . The standard deviation among children is $133,319.96$, while among adults 77800.07 . The coefficient of variation related to children is high at $17.89 \%$, and $14.42 \%$ with adults. The average positive rate of change in children is $0.09 \%$, and $0.05 \%$ in adults, indicating an increase in the poor population in both categories.

The percentage of poverty by the head of household education. The largest number of poor is recorded in the category of persons with incomplete primary education and primary education. It is evident that the level of education has a direct impact on the poverty level of society. The category of the population with college or university education is evident as the lowest percentage of poor people.

Table 6. The percentage of poverty by the head of household education in RS

\begin{tabular}{ccccccc}
\hline Education & $\begin{array}{c}\text { Average } \\
\bar{X}\end{array}$ & \multicolumn{2}{c}{ Interval variation } & $\begin{array}{c}\text { Standard } \\
\text { deviation }\end{array}$ & $\begin{array}{c}\text { Coefficient of } \\
\text { variation } C_{\boldsymbol{v}} \\
\text { (\%) }\end{array}$ & $\begin{array}{c}\text { Rate } \\
\text { changes } \\
\boldsymbol{r}(\%)\end{array}$ \\
\hline $\begin{array}{c}\text { Uncompleted } \\
\text { primary } \\
\text { school }\end{array}$ & 1.144 .910 & 661.520 & 1.556 .429 & $309.111,23$ & 27,00 & $-1,01$ \\
$\begin{array}{c}\text { Primary } \\
\text { school }\end{array}$ & 872.211 & 673.514 & 1.015 .385 & $129.149,25$ & 14,81 & $-0,23$ \\
$\begin{array}{c}\text { Secondary } \\
\text { school }\end{array}$ & 345.733 & 219.624 & 407.636 & $67.229,65$ & 19,45 & $-0,38$ \\
$\begin{array}{c}\text { High school } \\
\text { Higher school }\end{array}$ & 111.415 & 7.382 & 198.456 & $73.942,76$ & 66,37 & 3,48 \\
\hline
\end{tabular}

Source: Social Inclusion and Poverty Reduction Unit and Statistical Office of the Republic of Serbia, 2012; author's calculation.

The highest average number of poor people in Serbia belongs to the category of people with incomplete primary education $(1,144,910)$, and the lowest category of the population with higher education $(80,969)$. Interval of variation of the population of primary school leavers ranges from 661,520 to $1,556,429$, while the population of high school goes from 29,526 to 139,654 . When the population of primary school leavers standard deviation is $309,111.23$, the coefficient of variation is at $27.00 \%$ and a negative rate of change at $-1.01 \%$, which indicates a decline in the average number of poor people in the five-year period. The population with a high school standard deviation is $73,942.76$, the coefficient of variation is at $57.20 \%$ and a negative rate of change at $-2.05 \%$, which indicates a decline in the average number of 
poor people in the five-year period. The increase in the average number of poor people is recorded only in the category with higher education, where the rate of change is of $3.48 \%$.

The percentage of poverty by socio - economic status of the household head. The highest percentage of poor by this indicator belongs to a group of unemployed which in 2010 was $17.9 \%$, and to other non-active population of $17.1 \%$.

Table 7. The percentage of poverty by socioo - economic status of the household head in RS

\begin{tabular}{|c|c|c|c|c|c|c|}
\hline \multirow{2}{*}{$\begin{array}{c}\text { Socio - } \\
\text { economic } \\
\text { status of the } \\
\text { head of } \\
\text { household } \\
\end{array}$} & \multicolumn{4}{|c|}{ Interval variation } & \multirow[b]{2}{*}{$\begin{array}{l}\text { Coefficient of } \\
\text { variation } C_{v(\%)}\end{array}$} & \multirow[b]{2}{*}{$\begin{array}{c}\text { Rate } \\
\text { changes } \\
r(\%)\end{array}$} \\
\hline & $\begin{array}{c}\text { Average } \\
\bar{X}\end{array}$ & Min & Max & $\begin{array}{l}\text { Standard } \\
\text { deviation }\end{array}$ & & \\
\hline Self-employed & 616.390 & 374.861 & 804.592 & $174.859,77$ & 28,37 & $-0,17$ \\
\hline Employees & 355.839 & 286.659 & 391.224 & $39,546,63$ & 11,11 & $-0,04$ \\
\hline Unemployed & 1.144 .518 & 804.592 & 1.305 .167 & $185.790,14$ & 16,23 & 0,45 \\
\hline Retirees & 504.706 & 418.963 & 652.218 & $88.602,53$ & 17,56 & $-0,95$ \\
\hline Other inactive & 1.681 .504 & 1.139 .284 & 2.144 .996 & $418.491,35$ & 24,89 & $-1,28$ \\
\hline
\end{tabular}

Source: Social Inclusion and Poverty Reduction Unit and Statistical Office of the Republic of Serbia, 2012; author's calculation.

The lowest average number of poor people is realized in the category of employees $(355,839)$ and the highest in the category of inactive, others $(1,681,504)$. The number of poor in the group of the employed population ranged from 286,659 to 391,224 , the standard deviation is $39,546.63$, the coefficient of variation is $11.11 \%$ and has achieved a slight decrease of the poor population of $-0.04 \%$. The number of poor in the group remained inactive population ranged from $1,139,284$ to $2,144,996$, the standard deviation is $418,491.35$, the coefficient of variation is $24.89 \%$ and has achieved the highest negative rate of change of $-1.28 \%$ and the group decreased the category of poor population in the five-year period.

\section{Conclusion}

Generally, in the observed five-year period, the absolute and relative poverty line was rising (the value of a monthly food basket), while the poverty rate varies (in the period of $2006-2008$ decline, and in the period 2008-2010 growth). In accordance with previous findings for both forms of expression the percentage of the poor population, it is reasonable and obvious explanation that 
there is a simultaneous increase in unemployment and inflation, which in turn affects the growth rates of poverty Serbian ( Grujic et al., 2013).

The results show that the five-year period (2006-2010) have greater increase in the poor population as evident in the urban $(0.14 \%)$ than in non-urban areas $(0.01 \%)$, and on average there were 395,510 poor people. The Belgrade area recorded positive poverty rate of $0.48 \%$, Central Serbia $0.25 \%$ and Vojvodina recorded a negative growth of $-0.63 \%$ in poverty. The highest positive rate of change in the number of the poor is recorded among households of five members $(0.82 \%)$ and the highest negative record is noticed in single households $(-1.11 \%)$. The highest percentage of poor population belongs to the category of adults 19 to $24(1.14 \%)$, while the reduction of the poor population is recorded in the category of children aged 14 to 18 years $(-0.67 \%)$. The categories of the population with college or university education is evident as the lowest percentage of poor people, but with the greatest increase in rates of change in the analyzed period (3.48\%). Considering the socio - economic status of the household the highest percentage of poor people belong to the category of the unemployed, but the positive rate of change $(0.45 \%)$ is indicating their constant growth.

The best overview of the number of poor people is manifested with rate of changes. Consequently, the positive rate of change of its continual growth of the poor population in the five-year period is: urban and rural areas, areas of Belgrade and Central Serbia, the five-member and three-member household, adults from 19 to 24 years and heads of households with a college education .

Also, the negative rates of change of the poor were calculated, which indicates their continuous decline: the region of Vojvodina, one-person and two-person households, children aged 14 to 18 and older than 65 years or more, and heads of households who have completed high school.

Generally, social development, as a component of local development, refers to a wide range of social issues and reasons that need answering. The strategic goal of sustainable development in the area of social protection is to provide an efficient service based on a developed network of institutions that are able to eliminate or mitigate the risks they are exposed to the public.

Poverty is more pronounced in rural areas because of the salaries amount, infrastructure development, income and the like are smaller. But, whether it is rural poverty causing poor demographic structure of the population, or some other reason, the social policy of the state would have to be the same for all residents of Republic of Serbia. The fact that someone who is poor live in rural areas should not lead to the reduction of the rights that all citizens of the Republic of Serbia have(Živkov, et al, 2012). 


\section{References}

Božić, D., Munćan, P., Bogdanov, N. (2006) "Ekonomsko-socijalna obeležja porodičnih gazdinstava Srbije”, Ekonomika poljoprivrede, Specijalni broj: 399-408.

Cvejić, S., Babović, M., Petrović, M., Bogdanov, N., Vuković, O. (2010) Socijalna isključenost u ruralnim oblastima Srbije, UNDP Srbija, Sektor za inkluzivni razvoj, str. 32-34.

Grujić, B., Roljević, S., Kljajić, N. (2013) "Categorization of poverty in the Republic of Serbia in the period 2006-2010. " Economics of Agriculture, 2(2013): 309-320.

Kronja, J., Avlijaš, S., Matejić, V., Todić, D., Kovačević, A., Branković, J. (2011) Vodič kroz strategiju Evropa 2020, Evropski pokret Srbija, Beograd, str. 8. (http://www.emins.org/sr/publikacije/knjige/11-vodic-kroz-evropu-2020.pdf)

Novković, N., Mutavdžić, B., Ivanišević, D., Tešić-Miličić, M. (2011) „Stanje $i$ perspektive razvoja stočarstva u Vojvodini “, Škola biznisa 1(2011): 89-100.

Popović, V., Milovanović, M., Tomić, D. (2008) "Podrška poljoprivredi i ruralnom razvoju u funciji smanjenja siromaštva u Srbiji”, Ekonomika poljoprivrede, 1(2008): 69-82.

Social Inclusion and Poverty Reduction Unit $h t t p: / / w w w . i n k l u z i j a . g o v . r s / ? p a g e \_i d=1490$;

Social Inclusion and Poverty Reduction Unithttp://www.inkluzija.gov.rs/?page id $=3179 \&$ lang $=c s$

Social Protection Committee (2011) SPC ASSESSMENT OF THE SOCIAL DIMENSION OF THE EUROPE 2020 STRATEGY (2011) REPORT - 10 February 2011, COUNCIL OF THE EUROPEAN UNION, Brussels, pp. 10. (http://register.consilium.europa.eu/pdf/en/11/st06/st06624-ad01.en11.pdf)

Vlada Republike Srbije (2010) Srbija 2020: Koncept razvoja Republike Srbije do 2020. godine - Nacrt za javnu raspravu, Beograd

Vlada Republike Srbije (2011) Kratak pregled 1. nacionalnog izveštaja o socijalnom uključivanju $i$ smanjenju siromaštva u Republici Srbiji, uloga lokalnih samouprava, Tim za socijalno uključivanje i smanjenje siromaštva, Beograd

Živkov, G., Marković D., I., Tar, D., Božić, M., Milić, B., Paunović, M., Bernardoni, P., Marković, A., Teofilović, N. (2012) Budućnost sela u Srbiji, Tim za socijalno uključivanje i smanjenje siromaštva, Kabinet potpredsednice Vlade za evropske integracije, Beograd, Srbija, str. 140.

\section{TENDENCIJE PROMENE SIROMAŠTVA REPUBLIKE SRBIJE U PERIODU 2006-2010.}

Apstrakt: Svrha istraživanja je sagledavanje siromaštva u Republici Srbiji u periodu 2006-2010. godina. U radu je analiziran procenat siromašnih prema: tipu naselja, regionalnoj rasprostranjenosti, tipu domaćinstva, godinama starosti, učešću dece i odraslih, stepenu obrazovanja i socioekonomskom položaju nosioca domaćinstva. Primenjene su sledeće metode deskriptivne statistike: prosečna vrednost pojave, interval varijacije, standardna devijacija, koeficijent varijacije i stopa promene. Ukazano je i na razlike $u$ vrednosti potrošačke jedinice izražene $u$ dinarima, koje se koriste kao prag za utvrđivanje procentualno siromašnog stanovništva. Rezultati istraživanja ukazuju da su najsiromašnija višečlana domaćinstva i odrasli od 19 godina do 24 godine.

Ključne reči: siromaštvo, procenat siromašnih, prag siromaštva, aspekti siromaštva, statistički pokazatelji. 